DOI http://dx.doi.org/10.18551/rjoas.2016-02.07

\title{
DETERMINANTS OF INCOME DIVERSIFICATION AMONG FARM HOUSEHOLDS IN NIGER STATE, NIGERIA
}

\author{
Sallawu H., Tanko L., Nmadu J.N., Ndanitsa A.M. \\ Department of Agricultural Economics and Extension Technology, \\ Federal University of Technology, Minna, Nigeria \\ E-mail: realhalma@yahoo.com
}

\begin{abstract}
Poverty incidence in Nigeria is higher among the rural-folks, that is, households that rely mainly on agricultural income. Income diversification is therefore seen as a way to secure income and to increase welfare of the farm households. This study investigated determinants of income diversification among farm households in Niger State, Nigeria. The study utilized data obtained from administering questionnaire to 287 farming households. Data were analyzed using descriptive statistics, and Tobit regression model. The study revealed that mean age, household size, and farm size of the respondents were 42, 7, and 2.82 respectively. A total of $46.4 \%$ of the respondents had no formal education and only $12.9 \%$ had attained formal education up to the tertiary level. Majority that is $94.8 \%$ had no access to credit. Results of the Tobit regression revealed that farm size, age, level of education, farm income, non-farm income, credit use, livestock ownership, household size, poverty status, and occupation were the significant determinants of income diversification in the study area. The study recommends increase in the level of literacy among rural farm households. The impact of institutional credit on employments has been shown which ought to require taking comprehension of this basic by the approach system of the State as a vital advancement issue at the grass root. And in addition, government should re-energize and re-invigorate the extension service division of the State Ministry of Agriculture through capacity building, training and provision of necessary equipment to carry out its functions since they are the only group that understands the farmers' needs and idiosyncrasies.
\end{abstract}

\section{KEY WORDS}

Farm households, income diversification, livelihood strategies, non-farm income, Tobit regression.

Diversification as a rustic work system is utilized as a part of modifying possibilities with a specific end goal to boost return, spread dangers, or accomplish other family objectives. By keeping the capability to operate a heterogeneous set of activities, diversifying households are likely to enjoy higher flexibility and enhanced income resilience capacity than agricultural dependent rural households (Warren, 2002). Diversification and strong linkages among different components of the farming system have a synergistic effect on the functioning of the entire farming system and result in higher income (Kumar and Upadhyay, 2009). According to the DFID (2001), the term livelihood strategies denote; the range and combination of activities, and choices that people make in order to achieve their livelihood goals. Diversification is a norm, especially among agricultural households, whose livelihoods are vulnerable to climatic uncertainties (Barrett, Reardon, and Webb, 2001). Mishra, El-osta, Morehart, Johnson, and Hopkins (2002) observed that off-farm work is normally considered less risky than farming. They also argued that a risk-averse farm household would be more likely to engage in non-farm work than a less risk-averse farm household. Idowu, Aihonsu, Olubanjo, and Shittu (2011) reveals that age, gender, education, experience in the particular non-farm activity, household size, per capital landholding, distance to urban centre and investment asset base of the households were the major determinants of income shares from different sources of non-farm activities. And also increase in the size of household, per capital landholding and per capital animal wealth significantly increased the income diversification of the rural farm households, while reduction in household dependency ratio 
and distance to urban centres significantly decreased income diversification. Few attempts have been made to link the tendency for farm households to engage in multiple occupations to poverty reduction in the study area.

There are a number of factors which affect the household income such as the age of the household head, availability of labour in the household for work, household size, and educational level of the household, possession of land and also having accessibility to other natural resources and having the income from remittances. At the community and regional level, the household income is also affected by a wide range of factors such as access to markets and the infrastructure of the region. Among the institutional factors public policy, regarding access to credits, extension and research facilities are important. Similarly, biophysical factors also affect the household income. The regular occurrence of diseases, presence of disable member of household and the presence of such climatic factors or conditions which are not supportive to the household for increasing the income. The economic factors also affect the household income (Gordon and Craig, 2001).

Diversification is expansion in the importance of non-crop or non-farm income and increase in the number of sources of income (Minot, et. al., 2006). Livelihood literature (Hussein and Nelson 1999; Ellis 2000) suggests that though exogenous trends and shocks play an important role in pushing rural people towards a diversified livelihood strategy, diversification choices are also firmly rooted in the micro-economic logic of farming households. Availability of key-assets (such as savings, land, labor, education and/or access to market or employment opportunities, access to common property natural resources and other public goods) is a an evident requisite in making rural households and individuals more or less capable to diversify (Dercon and Krishan 1996; Abdulai and Crole Rees 2001). Investment of a proper mix of the above endowments is the starting move of any independent activity. Moreover, labor capability and education determine the capability of finding a job and savings are often needed to migrate. Yet, diversification may also develop as a coping response to the loss of capital assets needed for undertaking conventional onfarm production. Decreased availability of arable land, increased producer/consumer ratio, credit delinquency, and environmental deterioration can be indeed important drives towards diversification. Economic and political shocks are often a major reason for migrate.

Maximization of return per unit of labour (Ellis, 2000) is another important element in livelihood diversification choices. This principle foresees that, in any given point in time, a rural household will choose the most cost-effective opportunity to ensure maintenance of its consumption level. This formulation can be elaborated in different ways. For instance, availability of a surplus of household labour (or a high producer/consumer ratio) may influence the household decision to engage in wage labour. Similarly, food availability and food cost volatility on the local market can affect the relative importance attributed to selfconsumption production, and promote or prevent the undertaking of wage labor or engagement in income generating enterprises. Seasonality may also lead to a cyclical shift in time allocation from on farm to off-farm sources of revenue. Strengthening the household asset basis can be an additional important factor in diversification choices. In particular, members of better-off household can undertake innovative activities or engage in highly remunerative wage labour (migrate abroad) with the specific aim of accumulating savings needed to expand the land holding, offer education opportunities to the young generation, or insure themselves against illness and aging. In addition to that, diversification may also occur as a means to consolidate household natural capital (to enhance the environmental sustainability of a particular livelihood strategy). Gender relationships are also important in shaping diversification process. Social organization and culture can significantly influence the relative access of diverse gender (and age groups) to household's capital assets (Ellis, 2000) or constraint/promote their mobility. This might result in a different degree of involvement in diversification activities and/or in an unequal distribution of their benefits between genders (Warren, 2001). Chaplin, Davidova, and Gorton (2002) observed that size of household farms, level of farmer's education are the determinants of income diversification, and that diversification might be a feasible way out of vicious circle of fragmented farms, low productivity and poor profitability by improving the asset based and education of poorest 
farmers. Lending credence to this, Adebayo, Akogwu and Yisa (2012) pointed out that educational level, membership of cooperatives and non-farm income are variables that significantly increase income diversification of farm households while farm size decreases the income diversification of households. Bekelu and Abdi-khalil (2013) revealed that age, land size, and average distance from market have negative significant influence on the household's decision towards diversification, while family size, number of extension visit per year and education boost income diversification among small scale farmers.

The poor in Nigeria live in abject condition due to their low level of income with children under 5 years mortality rate of 124 in 2012 while life expectancy at birth in the country (52 years in 2012) is the $17^{\text {th }}$ lowest globally (UNDP, 2012). Apart from death due to starvation and other health hazards that the poor people are daily faced with, poverty induced hunger and malnutrition are known to impair Intelligence Quotient (IQ) development in children, leading to large loss in quality of life, and contributes to the declining productivity and poor economic growth in developing countries (United Nations System Standing Committee on Nutrition, 2004; Von Braun, 2005). This situation however, presents a paradox considering the vast human and physical resources that the country is endowed with. Farming deals with uncertain factors such as weather and market conditions. These uncertainties can result in variable returns (farm income) to the decisions farmers make in a particular year. Acute land constraint and absence of well operating land market may prevent households who possess particular skills or abundant labour from exploiting their comparative advantageous position, and seasonality of farming activity results in unemployment and underemployment for a significant proportion of the labour force during most periods of the year. Evidences abound that among the rural poor, the farming households are poorer. But the non-farm sector offers potential to absorb a growing rural labour force, slow rural-urban migration, contributes to national income growth, and promotes a more equitable distribution of income (Lanjouw, 1997; Fikru, 2008).

Considering the growing importance of non-farm activities, it is worthy of note, that the rural non-farm sector in Niger State, as it is in other parts of the country, is complex and characterized by diverse activities, whose labour and other resource requirements and returns are in no way homogenous. The findings of the study are also expected to indicate the policy interventions that might improve rural livelihoods to raise incomes and curb widespread poverty. Researchers will also find the body of literature useful in their quest to extend frontiers of knowledge. The objectives of this study were to describe the socioeconomic characteristics of the farm households, and analyse the determinants of income diversification among the farm households in the study area. The hypothesis was formulated for further empirical validation: Ho: The following explanatory variables do not significantly explain income diversification by farm households in the study area: farm size; age; occupation; household size.

\section{METHODOLOGY OF RESEARCH}

The study was conducted in selected Local Government Areas in Niger State of Nigeria. It is one of the 36 States of Nigeria, created out of the defunct North Western State on $3^{\text {rd }}$ February, 1976. Situated in the North central geo-political Zone, the State shares its borders with Zamfara State (North), Kebbi State (North West), Kogi State (South), Kwara (South West), Kaduna (North East) and the FCT (South East). The location of the State is between Latitudes $8^{\circ} 20^{1}$ and $11^{\circ} 30^{1}$ North of the Equator and also between Longitudes $3^{\circ}$ $30^{1}$ and $7^{\circ} 20^{1}$ East of the Greenwich Meridian. The provisional result of the 2006 National Population Census shows that the State has a population of 3,950,249 (NPC, 2006). Going by the population growth rate in Nigeria of $2.5 \%$ (World Bank, 2013), the population of the State was projected to 4,695,604 as at 2013. The State comprises 25 Local Government Areas grouped into three agricultural Zones: I, II, III, with each zone having 8, 9 and 8 Local Government Areas (LGAs) respectively. There are three major ethnic groups in the State, Nupes, Gbagyi, and Hausa. Other tribes are Kadara, Koro, Dibo, Kambari, Kakanda, Dukkawa, Dakarkari, Gana-Gana, Kamuku, etc. Niger State covers a total land area of 
$83,266,779$ kilometres or about 8.3 million hectares which represent $8 \%$ of the total land area of Nigeria. About $85 \%$ of the land is arable; the vegetation consists mainly of short and scattered trees. Soils are predominately light and well drained. The State experiences distinct dry and wet seasons with annual rainfall varying from $1,100 \mathrm{~mm}$ in the Northern part to $1,600 \mathrm{~mm}$ in the southern parts. The temperature ranges from $23^{\circ} \mathrm{C}$ to $37^{\circ} \mathrm{C}$ and daylight duration is averagely 8.5 hours and it has a relative humidity of $40 \%$. The major economic activity is agriculture (farming, fishing and livestock rearing).

Multi-stage sampling technique was employed in the collection of primary data for this study. In the first stage, one Local Government Area was randomly selected from each of the three agricultural zones namely, Zones I, II and III respectively. In the second stage, one community each was randomly selected from the selected LGAs, giving a total of 3 communities. In the third stage, sampling of farm households in each community was determined proportionately using Yamane's (1967) formula and adopted by Agu and Udoh (2012).

$$
\mathrm{n}=\frac{N}{1+N(e)^{2}}
$$

where: $\mathrm{n}=$ sample size; $\mathrm{N}=$ finite population; $\mathrm{e}=$ limit of tolerable error (level of significance $=0.05$ ) and $1=$ constant.

Data were collected using structured questionnaire. Data for this study was analyzed using descriptive statistics such as means, frequency, standard deviation, and Tobit regression analysis. To analyze the determinants of income diversification, Tobit model was used. This model is also referred to as a censored regression model. Owing to the restrictions imposed on the values taken by the dependent variable, the Tobit model is often referred to as limited dependent variable regression model.

Let $\mathrm{Y}$ be a variable that is essentially continuous over strictly positive values but takes on zero with positive probability.

The Tobit model is defined as a latent variable model:

$$
\begin{gathered}
Y_{i}^{*}=X_{i}^{*} \beta+\varepsilon_{i} \\
Y_{i}=\max \left(0, Y^{*}\right) \\
\text { Then, } Y_{i}=0 \text { if } Y^{*} \leq 0 \text { and } Y i=Y_{i}^{*} \text { if } Y_{i}^{*}>0
\end{gathered}
$$

The latent variable $Y^{*}$ satisfies the classical linear assumptions of normality and homoskedastic distribution with a linear condition mean. It also implies that the observed variable $Y_{i}$ equals $Y^{*}$ when $Y^{*}>0$, but $Y=0$ when $Y^{*} \leq 0$.

The estimated coefficients in a Tobit model cannot be interpreted the same way as in a Linear Regression Model. For discrete categorical variables, the marginal effects are used to calculate percentage changes in dependent variables when the variable shifts from zero to 1 , while for continuous variables, the marginal effects are used to calculate elasticity at complete means.

$$
\frac{\partial E[Y *]}{\partial X_{k}}=\beta_{\mathrm{k}}
$$

The implicit model was specified as:

$Y=f(f a r m$ size, age, education, gender, distance from market, number of extension visits, farm income, off-farm income, credit obtained, livestock holding, household size, occupation, poverty status).

The empirical Tobit model is explicitly specified as: 


$$
\begin{gathered}
Y^{*}=\beta_{0}+\beta_{1} F S Z+\beta_{2} A G E+\beta_{3} E H H+\beta_{4} G E N+\beta_{5} D F M+\beta_{6} E X T+\beta_{7} F I C+\beta_{8} N F I+\beta_{9} C R E+\beta_{10} L S H+ \\
\beta_{11} H H S+\beta_{12} \mathrm{OCC}+\beta_{13} P V S+e
\end{gathered}
$$

where:

$Y^{*}=0$ if the share of income from diversifying to off-farm is $5 \%$ and less than $5 \%$, and $Y^{*}=1$ for which income share from off-farm is greater than $5 \%$ where $Y^{*}$ is the share of income from off-farm activities;

FSZ = Farm size of household (hectares);

AGE = Age of household head (years);

$\mathrm{EHH}=$ Level of education (No. Of years spent in school);

GEN $=$ Gender of household head (binary variable: male $=1$, female $=2$ );

$\mathrm{DFM}=$ Distance of farm from main market $(\mathrm{km})$;

$\mathrm{EXT}=$ Number of extension contacts with extension agents during the last cropping season (Numbers);

$\mathrm{FIC}=$ Farm income realized $(\mathbb{A})$;

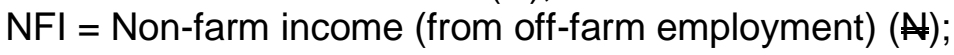

$\mathrm{CRE}=$ Credit use by farm household (A);

LSH = Livestock ownership by household ( $($ );

HHS = Household size (Numbers);

OCC = Occupation (Number of occupations);

PVS = Poverty status of the household head (poor $=1$, non- poor $=0$ );

e = error term;

$\beta_{0}=$ Intercept to be estimated;

$\beta_{1}-\beta_{13}=$ coefficients to be estimated.

Tobit regression model was used to test the hypothesis formulated for this study. In testing the hypothesis, the estimated regression coefficients in the Tobit model were used. The statistical significance of the estimated coefficients aided the confirmatory tests.

\section{RESULTS AND DISCUSSION}

Table 1 presents the socio-economic characteristics of the respondents which revealed that the average age of the respondents was 42 years, and just a couple of those studied are either excessively youthful or excessively old, making it impossible to participate in one activity or the other in the study area.

This infers pay that income diversification is common among the farm households headed by the youthful who are more fiery and could stand to bring the dangers connected with income diversification. This agrees with the findings of Awoniyi and Salman (2012), and Awotide, Kehinde and Agboola (2010) which pointed out that majority of the households that are engaged in non-farm income are still in their productive years. They are able to engage themselves in multiple income generating activities that can enhance the households' purchasing power and consequently their welfare status. From the analysis, household size in the study area is genuinely substantial with an average of 7 members. This is in line with the finding of Okere and Shittu (2012) who affirmed that larger households may have to depend on more income generating activities for sustainable livelihood than smaller sized households. Farming experience as depicted in Table 1 shows that an average of 26 years of experience. The implication of this is that the farm household heads would probably participate less in non-farm activities due to their high level of farming experience. The results further revealed that a typical respondent had 2.82 hectares. This implies that most of the respondents are subsistence-oriented farmers and income diversification will likely help raise their standard of living above the poverty level. Results in Table 1 further revealed that majority of the respondents accounting for $85 \%$ acquired their land through inheritance which encouraged farmland fragmentation. In terms of gender, Table 1 revealed that an overwhelming majority of the household heads were male representing $95.50 \%$. This is an indication that the males dominated agricultural activities. This agrees with the findings of 
Okere and Shittu (2012) who revealed that the males dominated the work force in Nigeria's agricultural communities.

Table 1 - Distribution of respondents according to socio-economic characteristics, $\mathrm{N}=287$

\begin{tabular}{|c|c|c|c|}
\hline Variables & Frequency & Percentage & Mean (Standard Dev.) \\
\hline \multicolumn{4}{|l|}{ Age } \\
\hline$<30$ & 20 & 7.00 & \\
\hline $30-39$ & 88 & 30.70 & \\
\hline $40-49$ & 110 & 38.30 & \\
\hline $50-59$ & 44 & 15.30 & \\
\hline$>59$ & 25 & 8.70 & $42(10.5)$ \\
\hline \multicolumn{4}{|l|}{ Household Size } \\
\hline $1-5$ & 134 & 46.70 & \\
\hline $6-10$ & 94 & 32.80 & \\
\hline $11-15$ & 40 & 13.90 & \\
\hline$>15$ & 19 & 6.50 & $7(4.8)$ \\
\hline \multicolumn{4}{|l|}{ Years of Experience } \\
\hline$<11$ & 16 & 5.60 & \\
\hline $11-20$ & 85 & 29.60 & \\
\hline $21-30$ & 116 & 40.40 & \\
\hline $31-40$ & 49 & 17.10 & \\
\hline$>40$ & 21 & 7.30 & $26(10.7)$ \\
\hline \multicolumn{4}{|l|}{ Farm Size } \\
\hline $0.5-2.0$ & 96 & 33.50 & \\
\hline $2.5-4.0$ & 64 & 22.30 & \\
\hline $4.5-6.0$ & 78 & 27.20 & \\
\hline$>6.0$ & 49 & 17.00 & $2.8(2.4)$ \\
\hline \multicolumn{4}{|l|}{ Gender } \\
\hline Male & 274 & 95.50 & \\
\hline Female & 13 & 4.50 & \\
\hline \multicolumn{4}{|l|}{ Mode of Acquiring Land } \\
\hline Owned & 26 & 9.10 & \\
\hline Rented & 12 & 4.20 & \\
\hline Inherited & 244 & 85.00 & \\
\hline Leasehold & 5 & 1.70 & \\
\hline \multicolumn{4}{|l|}{ Educational Level } \\
\hline None & 47 & 16.40 & \\
\hline Quranic & 86 & 30.00 & \\
\hline Primary & 70 & 24.40 & \\
\hline Secondary & 47 & 16.40 & \\
\hline College of Education & 20 & 7.00 & \\
\hline College of Health Technology & 3 & 1.00 & \\
\hline Polytechnic & 6 & 2.10 & \\
\hline University & 8 & 2.80 & \\
\hline \multicolumn{4}{|l|}{ Credit accessibility } \\
\hline No & 272 & 94.80 & \\
\hline Yes & 15 & 5.20 & \\
\hline \multicolumn{4}{|l|}{ Extension Contact } \\
\hline No & 177 & 61.70 & \\
\hline Yes & 110 & 38.30 & \\
\hline Total & 287 & 100.00 & \\
\hline
\end{tabular}

Source: Field Survey, 2014.

In terms of level of education, only $12.9 \%$ had tertiary education in the study area. It can be seen that the literacy level of farm households in the study area was relatively low. This is in line with the findings of Awoniyi and Salma (2012) who pointed out that low educational level among farming households undoubtedly affect their income diversification patterns and that generally, there is a low level of education among the rural farming households and this has implications for their income-earning capacity as the respondents may lack the required skill to secure well paid jobs. Also, farmers may find it difficult to adopt modern improved techniques of production or operations because of their lack of education. Education enhances the technical competence and entrepreneurial spirit. Result in Table 1 
further indicated that most respondents in the target population $(94.80 \%)$ had no access to agricultural loan. Acquisition of additional capital enables farm households procures production inputs such as fertilizers, agrochemicals and to hire additional labour. Agricultural credit also has the propensity to break the vicious cycle of poverty and raise the purchasing power of farm households who over rely on meagre household resources. The results also revealed that $61.7 \%$ had no access to extension services. This implies that majority of the farm households in the study area had no access to innovations that probably would have increased their agricultural output so as to increase their total income.

Tobit regression model was used to identify factors that influenced income diversification among farm households in the study area. The results in Table 2 reveal that ten out of thirteen variables were statistically significant at explaining income diversification of farm households.

Table 2 - Estimates obtained from the Tobit regression model on the determinants of income diversification

\begin{tabular}{|c|c|c|c|}
\hline Explanatory variables & Coefficient & t-ratio & Marginal Effects \\
\hline Constant & 0.872 & $5.730^{\star \star \star}$ & \\
\hline Farm size & -0.017 & $-3.890^{\star * *}$ & -0.017 \\
\hline Age of household head & -0.003 & $-2.800^{\star \star *}$ & -0.003 \\
\hline Level of education & 0.003 & $2.420^{* *}$ & 0.003 \\
\hline Gender of household head & 0.005 & 0.180 & 0.005 \\
\hline Distance to main market & -0.002 & 1.960 & -0.002 \\
\hline Number of extension contact & -0.003 & -1.900 & -0.003 \\
\hline Farm income & 0.051 & $3.250^{\star * *}$ & 0.051 \\
\hline Non-farm income & 0.071 & $5.100^{\star * *}$ & 0.071 \\
\hline Credit use & 0.003 & $2.510^{\star *}$ & 0.003 \\
\hline Livestock ownership & 0.009 & $4.830^{* * *}$ & 0.009 \\
\hline Household size & 0.005 & $2.360^{* *}$ & 0.005 \\
\hline Occupation & -0.071 & $-3.300^{\star * \star}$ & 0.071 \\
\hline Poverty status & 0.008 & $2.020^{* *}$ & 0.007 \\
\hline \multicolumn{4}{|c|}{$\begin{array}{l}\text { Log likelihood }=-176.37729 ; \text { LR } \text { chi }^{2}(13)=97.74^{* * *}\left(\text { prob. }>\text { chi }^{2}=0.0000\right) \\
\text { Pseudo } R^{2}=0.3833 \text {, number of observations }=262 \text {. } \\
{ }^{\star * *} p<0.01,{ }^{\star *} p<0.05 \text { and }{ }^{*} p<0.10 \text { significant level. }\end{array}$} \\
\hline
\end{tabular}

Source: Field Survey, 2014

The likelihood ratio statistic as indicated by $\chi^{2}$ statistics (97.74) was significant at the 0.01 probability level, (prob. $>$ chi $=0.0000$ ) suggesting that the model had a strong explanatory power. The results of the marginal effects are also presented in Table 2. Farm size was found to be negatively signed and significant at the 0.01 probability level. This is in agreement with a priori expectation of a negative relationship with income diversification. Various studies on the relationship between farm size and off-farm income have also reported an inverse relationship (Fikru, 2008; Awoniyi and Salman, 2012; Adebayo et al., 2012). The possible reason for this is that, as farmers' farm size increases, they will require more time and labour to cultivate the land. This is also consistent with the finding of Bekelu and Abdil-Khalil (2013) who revealed that farmers with relatively larger area of farm land tended to involve more in farming activities than those farmers who have smaller areas of farm land to cultivate. The coefficient of age of the household head was negatively signed and significant at the 0.01 probability level. This was in agreement with a priori expectation of a negative relationship with income diversification. This finding was in consonance with Awoniyi and Salman (2012) who found out that age of household head and farm size reduces the likelihood that farming households would engage in non-farm income. Strength of the household head as they become older or their working potential at old age could be a probable reason for decrease in participation in non-farm activities. This also agrees with the findings of Fikru (2008) who affirmed that as the household head gets older, he/she is expected to be less active and hence would rely more on farm than non-farm income. This agrees with the ideology that farming in subsistent agriculture is considered a way of life and 
not organized as a business enterprise. The coefficient of educational level was positive and statistically significant at the 0.05 probability level as expected. It was hypothesized that the educational attainment of the household head tends to increase the likelihood of income diversification, because education tends to open more employment opportunities for income generation i.e it is vital for boosting the productivity of human factor, making people to be aware of more opportunities for generating income from different sources. Various studies on the relationship between education and non-farm income have also reported a direct relationship (Ibekwe et al., 2010; Bekelu and Abdil-Khalil, 2013; Adebayo et al., 2012). This is also consistent with the findings of Minot et al. (2006) who found out that education facilitates access to a number of different economic activities, either as a formal requirement for wage earning jobs or because it helps setting up and managing own small businesses.

Results in Table 2 further revealed that, the coefficient of farm income was positively signed and statistically significant at the 0.01 probability level. This result conforms to the $a$ priori expectation of a positive relationship with income diversification. This is because, farm income can be a source of investment for non-farm activities, especially in situations where lack of liquidity and access to credit are critical barriers to entry, income derived from crop and livestock can hence support diversification strategies of farm households. The purpose of income diversification is to increase the non-farm income so as to raise the standard of living of the farm household. This was suggested by the coefficient of non-farm income which was positive and statistically significant at the 0.01 probability level, indicating that an increase in non-farm income will lead to increase in diversification. This is in agreement with the a priori expectation and finding by Adebayo et al. (2012) who ascertained that non-farm income increases income diversification by farm households. Credit use by the respondents had a positive coefficient and statistically significant at the 0.05 probability level in determining income diversification which conforms to the a priori expectation. This implies that access and utilization of household's credit facility could probably lead to engagement in other businesses to improve their standard of living. This is in line with the findings of Demissie (2003) who pointed out that credit was found to be a significant determinant of the level of income diversity for more lucrative strategy, implying that credit enabled households to widen their income earning options.

The observed positive regression coefficient of livestock ownership which was statistically significant at the 0.01 probability level suggested that the variable was a determinant of household participation in non-farm activities. This is consistent with studies done by Demissie (2003), and Fikru (2008) whose findings revealed that apart from serving as accumulation of wealth and social prestige, livestock holdings generate income through sale of animals and animal products (milk, butter, and cheese), and provide transport services. Livestock endowment seems, therefore to be an important asset for enhancing diversification and it had a positive effect on livelihood diversification through different channels; namely, reducing risk aversion attitude of households, relieving liquidity constraints and, generating income through sale of its products and services. The coefficient of household size was positive and statistically significant at the 0.05 probability level which is in agreement with the a priori expectation. It was hypothesized to have a positive influence on diversification because, households with large sizes, coupled with the prevailing economic hardship in the country, may resort to search for alternative sources of income to supplement those from their main occupation. This is in line with the findings of Ibrahim and Onuk (2009) who found out that household with a very high ratio of dependants had a higher tendency to diversify into non-agricultural activities in order to feed the gaping mouths and to cope with the needs of the household. The coefficient of occupation was negative and statistically significant at the 0.01 probability level which is in agreement with the a priori expectation. It was hypothesized to have a negative influence on diversification, the possible reason for this, is that as the number of occupation of the farm household head increase they will tends to diversify less due to the time available to take care of many different income generating activities. This is in line with the findings of lbekwe et al. (2010) who found out that occupation and age of household head are important factors for non-farm income at the household level. The coefficient of poverty status of the respondents was also positive and 
statistically significant at the 0.05 probability level which is in agreement with the a priori expectation. This implies that poor farming households will probably need to engage themselves in multiple income generating activities so as to increase their purchasing power. This is in consistent with the findings of Awoniyi and Salman (2012) and Oluwatayo (2009) who identified poverty status of households as one of the factors that determines the likelihood that rural households would diversify their income.

The null hypothesis stated that farm size, age, occupation and household size do not significantly explain income diversification by households in the study area. The result of the Tobit model in Table 2 indicated that the farm size, age, occupation, and household size with coefficients of $-0.017,-0.003,-0.071$, and 0.005 respectively were statistically significant at explaining the income diversification. The null hypothesis $(\mathrm{Ho})$ is here by upheld in respect to farm size, age, occupation, and household size. The implication of this finding is that income diversification is influenced by farm size, age, household size, and occupation of the farm household.

\section{CONCLUSION}

The study concluded that farm size, age, and occupation were the negative determinants of income diversification. While level of education, farm income, non-farm income, credit use, livestock ownership, household size, and poverty status were the positive determinants of income diversification in the study area. The study therefore, recommends that the level of literacy among rural farm households, and financial markets should be looked into when formulating policy and developmental issues as they influenced livelihood diversification, government should re-energize and re-invigorate the extension service division of the State Ministry of Agriculture through capacity building, training and provision of necessary equipment to carry out its functions since they are the only group that understands the farmers' needs and idiosyncrasies.

\section{REFERENCES}

1. Abdulai, A. \& Crole R. A. (2001). Determinants of Income Diversification amongst Rural Households in Southern Mali. Food Policy, 26(1), 437-452.

2. Adebayo, C. O., Akogwu, O. G., \& Yisa, E. S. (2012). Determinants of Income Diversification Among Farm Households in Kaduna State: Application of Tobit Regression Model. Production Agriculture and Technology Journal, 8(2), 1-10. Retrieved from www.patnsukjournal.net/currentissue. Accessed on 16 February, 2014.

3. Agu, A. O., \& Udoh, B. E. (2012). Impact of Job Satisfaction on Organisational commitments among Secondary School Teachers in Enugu State. African Journal of Education and Technology, 2(1), 119-136. Retrieved from www.sachajournal.com. Accessed on $2^{\text {nd }}$ December, 2014.

4. Awoniyi, O. A. \& Salman, K. K. (2012). Non-Farm Income Diversification and Welfare Status of Rural Households in South West Zone of Nigeria. International Food Policy Research Institute (IFPRI) Paper. Pp. 1-14.

5. Awotide, O. D., Kehinde, A. L., \& Agbola, P. O. (2010). Poverty and Rural Livelihood Diversification Among Farming Household in South- West Nigeria. Journal of Food, Agriculture \& Environment, 8(1), 367-371. Retrieved on 16 January, 2013 from www.world.food.net.

6. Barrett, C. B., Reardon, T., \& Webb, P. (2001). 'Non-farm Income Diversification and Household Livelihood Strategies in Rural Africa: Concepts, Dynamics and, Policy Implications', Food Policy, 26(2), 315-331.

7. Bekelu, T. \& Abdi-khalil, E. (2013). Determinants and Patterns of Income Diversification among Smallholder Farmers in Akaki District, Ethiopia. Journal of Research in Economics and International Finance, 2(4), 68-78.

8. Chaplin, H., Davidova, S., \& Gorton, M. (2002). Non Agricultural Diversification of Farm Households and Corporate Farms in Central Europe. Paper presented at the 
International Agricultural Policy Reform and Adjustment Project (IAPRAP) in it series workshop on the Farm Household-Firm unit: Its importance in Agriculture and implications for statistics, April 12-13, 2002, Wye Campus, Imperial College, Durban South Africa.

9. Demissie, D. (2003). The Determinants and Impacts of Income Diversification in Rural Ethiopia: The Case of Communities in Southern Nations, Nationalities, and Peoples Regional State. M. Sc submitted to the School of Graduate Studies of Addis Ababa University.

10. Department for International Development (DFID) (2001). Sustainable Livelihoods Guidance Sheets. London.

11. Dercon. S., \& Krishnan, P. (1996). Income portfolios in rural Ethiopia and Tanzania: choices and constraints. Journal of Development Studies, 32(6), 850-875.

12. Ellis, F. (2000). Rural livelihoods and Diversity in Developing Countries. London: Oxford University Press. Pp. 1-10.

13. Fikru, T. (2008). A Case Study of Non-farm Rural Livelihood Diversification in Lume Woreda, Oromiya Regional State, M.Sc. Thesis, School of Graduate Studies Lume Woreda.

14. Gordon, A., \& Craig, C. (2001). Rural Non-farm Activities and Poverty Alleviation in SubSaharan Africa. Policy Series 14. Chatham, UK: Natural Resources Institute.

15. Hussein, K., \& Nelson, J. (1999). Sustainable Livelihoods and Diversification. IDS Working Paper 69. London: Institute of Development Studies.

16. Ibekwe, U. C., Eze, C. C., Ohajianya, D. O., Orebiyu, J. S., Onyemauwa, C. S., \& Korie, O. C. (2010). Determinants of Nonfarm Income among Farm Households in South East Nigeria. Academia Arena, 2(8), 29-33.

17. Ibrahim, H. I., \& Onuk, G. E. (2009). Analysis of Rural Non-farm Diversification among Farming Households in Doma area of Nasarawa State, Nigeria. Production Agriculture and Technology Nasarawa State University Keffi Journal, 5(1), 49-54. Retrieved on 13 Sept. 2014 from www.patnskjournal.net/currentissue.

18. Idowu, A. O., Aihonsu, J. O. Y., Olubanjo, O. O., \& Shittu, A. M. (2011). Determinants of Income Diversification among Farm Households in South-West Nigeria. Economics and Finance Review. 1(5), 33-34. Retrieved from http://www.businessjournalz.org/efr. Accessed on 15 January, 2013.

19. Kumar, S., \& Upadhyay, A. D. (2009). Goat farmers' Coping Strategies for Sustainable Livelihood Security in Arid Rajasth: An Empirical Analysis. Journal of Agricultural Economics Research Review, 22(12), 281-290.

20. Lanjouw, J. O., \& Lanjouw, P. (1997). The Rural Non-farm Sector: An update. (Drafted Paper) Washington D.C: World Bank.

21. Minot, M., Epprecht, M., Anh, T., \& Trung, L. (2006). Income Diversification and Poverty In the Northern Uplands of Vietnam, International Food Policy Research Institute, Wishington, DC.

22. Mishra, A. K., El-osta, H., Morehart, M., Johnson, J., \& Hopkins, J. (2002). Income, Wealth And Economic Well-being of Farm Households. Department of Agricultural Economics Report 812, 2002.

23. National Population Commission (NPC) (2006). Population Data in Nigeria. Retrieved on February 20, 2013 from http://www.population.gov.ng/population-data-in-Nigeria.

24. Okere, C. P., \& Shittu, A. M. (2012). Patterns and Determinants of Livelihood Diversification among Farm Households in Odeda Local Government Area, Ogun State, Nigeria. Paper Presented at the Nigerian Association of Agricultural Economist Conference held at Obafemi Awolowo University, Ile-Ife between 25-27 September, 2012. Theme: Agriculture in the National Transformation Agenda: The Policy Mix.

25. Oluwatayo, I. B. (2009). Poverty and Income Diversification Among Households in Rural Nigeria: A Gender Analysis of livelihood Patterns. A paper presented at The $2^{\text {nd }}$ Instituto de Estudos Sociais e Económicos (IESE) Conference on 'Dynamics of Poverty and Patterns of Economic Accumulation in Mozambique' in Maputo, Mozambique, 22-23 April, 2009. Accessed on 2 February, 2014. 
26. United Nations System Standing Committee on Nutrition (UN/SCN) (2004). $5^{\text {th }}$ Report on 27. the World nutrition situation. United Nations, Geneva.

28. United Nations Development Programme (2012). The Sustainable Future we Want. Retrieved from www.undp.org/.../undp/.../annaul-report-2012-the-sustainable-future. Accessed on 2 March, 2014

29. Von Braun, J. (2005). The World Food Situation: An overview. Paper presented at the CGIAR Annual General Meeting, held December 6, 2005 at Marrakech, Morocco.

30. Warren, P. (2001). Distance Survey on Gender Impacts of Commercialization. Manuscript. ROME: FAO, AGSP.

31. Warren, P. (2002). Livelihoods Diversification and Enterprise Development: An Initial Exploration of Concepts and Issues. Livelihood Support Programme (LSP) Working Paper 4. Food and Agricultural Organization of the United Nations.

32. World Bank, (2013). Nigeria Population Growth.

33. Yamane, T. (1967). Statistics: An Introductory Analysis, $2^{\text {nd }}$ Ed., New York: Harper and Row. 